\title{
Imagining Alternativas to Global, Corporate, New Economy Academic Capitalism
}

\author{
GARY RHOADES \& ALMA MALDONADO-MALDONADO \\ University of Arizona, USA \\ IMANOL ORDORIKA \\ Universidad Nacional Autonoma de Mexico \\ MARTÍN VELAZQUEZ \\ University of Arizona, USA
}

\begin{abstract}
In this article, the authors detail the conditions and patterns of academic capitalism and the new economy in US higher education.

Subsequently, a conceptual model is offered for considering the international reach and national and local patterns of academic capitalism. Further, a distinctive Mexican case of entrepreneurialism is offered. The article concludes with a discussion of alternatives for a model of a universidad latinoamericana that is grounded in the historical role of Latin American universities.
\end{abstract}

In a post-Soviet world, there seems to be little alternative to a market-based economy. From one country to the next, the prevailing political ideology is neo-liberalism, promoting a marketizing of public-sector enterprises. In this context, there seems to be little alternative in higher education to what Slaughter \& Leslie (1997) and Slaughter \& Rhoades (2004) have called 'academic capitalism'. The intersection of the new economy, global corporations, and universities has been most studied in the advanced Western world (Clark, 1998; Currie \& Newson, 1998; Marginson \& Considine, 2000; Bok, 2003). At the turn of the twentieth century the US model of entrepreneurial universities and of university engagement with the corporate world and the marketplace has become a dominant policy model of higher education, just as the German Humboldtian model was at the turn of the last century. And in both cases, the model that is being promoted, and that is eventually adapted, is often in many ways unlike the original model (see Amy 
Chua's [2003] book, World on Fire, in which she argues that Western/US models of the market economy and of democracy have been adapted in developing countries in ways that diverge significantly from their origins, particularly in terms of an absence of institutional infrastructures surrounding them). Clearly, the US model has been and continues to be aggressively promoted by international entities such as the World Bank as the only feasible and realistic policy choice and route to growth for developing countries. And just as clearly, oftentimes the move to the market in the higher education systems of other countries in some regards proceeds much further and to a greater, unrestricted, extreme than it has in the USA.

Yet we believe that there are realistic and realizable alternatives to the prevailing American model of academic capitalist universities. In this article, we draw particularly on examples from Latin America to imagine alternativas. Ironically, we find some of these alternatives embedded in a different balance of structures and commitments in a private Mexican university. We also find alternatives embedded in European traditions of Latin American public universities, which offer the possibility of a forward-looking conception of a universidad latinoamericana. Such an alternativa would address the varied cultural, political, social, and economic needs of the local communities and nations in which the institutions are positioned, even as it would create a space for a modelo distintivo global of what a university can be.

In the initial pages of our article we briefly set out the conditions and patterns of academic capitalism and the new economy in US higher education. In the process, we identify a few problems with that model related to what constituencies and communities entrepreneurial universities prioritize. Subsequently, we detail a conceptual model for considering the international reach and the national and local patterns of academic capitalism. Then, we offer an example of a distinctive Mexican entrepreneurial alternative, with the case of a leading private university. Finally, we develop a discussion of the historical role of Latin American universities in their societies, and we begin to imagine some future, distinctive alternatives for a model of a universidad latinoamericana that is different in important ways from the prevailing academic capitalist model.

Universities have long engaged in market-like behavior. However, recent decades have witnessed the emergence of 'academic capitalism in the new economy', a regime of policies and practices that involve colleges and universities engaging in market and market-like behaviors (Slaughter \& Rhoades, 2004). Those practices extend to higher education's central research, educational, and service functions. In the USA, colleges and universities are not simply partnering with business, they are developing, marketing and selling products commercially in the private-sector marketplace. Essentially, they are looking to generate profits, whether that is through patents and technology transfer, through the technologically mediated delivery of education and educational materials, or through various non-academic consumption items. The move in this direction has involved a revision and creation of policies to 
make these activities possible. The relationship between states, their higher education institutions and private-sector organizations is changing, as the boundaries between the for-profit and not-for-profit sectors are being blurred. Within higher education this has meant foregrounding market and potential revenue generation in policy negotiation and in strategic and academic decision making.

The changes embedded in academic capitalism and in the new economy are not simply about revenue generation. They are also about the new, socalled information-based economy. That has meant the development of new networks with high-tech businesses and industries.

At the same time as these developments in US higher education have taken place, we have witnessed the ascendance of neo-liberal policies nationally and internationally. Such policies shift government investment in higher education. They emphasize colleges' and universities' economic role and costefficiency. They involve institutions aiming to generate more of their own monies, to connect more closely to private corporations, and to be more efficient in and accountable for their use of public monies. Over time, then, conceptions of higher education as a producer of public goods and a cultural project have become more marginal, in the face of a conception of higher education as a private good.

What this has meant in the USA is a shift in institutions' orientations in important ways, not only to employers but also to 'customers'. The emphasis on revenue generation has meant an increased emphasis on connections with large versus with small and medium sized corporations (the new economy focus has meant as well a shift in the types of business and sectors of industry with which higher education intersects). It has also meant a shift in the target student populations, towards students with a greater ability (and willingness) to pay more to gain access to higher education (Slaughter \& Rhoades, 2004). Academic capitalism in the new economy is not neutral about who it serves. It focuses attention on the highest bidders, among employers and students. Perhaps the most dramatic example of this is among community colleges, which are increasingly intersecting with international student markets (they can charge these students higher tuition). The 'community' orientation in terms of student access is shifting not only with the pursuit of international students but also with the growth of distance education. Again, one of the reasons for this is that colleges can charge these students higher fees; there is also a hope that high-tech delivery costs will reduce labor costs. In short, the pattern of academic capitalism in the new economy encourages institutions to incorporate more of their activities into the global economy and to, in relative terms, disinvest in activities, programs, and students that are centered in the immediate locale and region. 


\section{Influencias y Mecanismos Globales de Capitalismo Académico}

One of the principal perspectives for conceptualizing and analyzing globalization is to consider it as the 'natural continuation of capitalism', as 'another stage of its development' (Waters, 1995). According to this perspective, globalization relates directly and naturally to neo-liberal policies and practices. However, we do not see the connection as one that naturally unfolds in a structured sequence of stages of capitalism. Rather, we focus on the international agencies and human agency that are involved in mediating and translating influences between international, national, and local social systems (Marginson \& Rhoades, 2002). In particular, in this section, we focus on the role of international organizations in shaping higher education policy and practice. These organizations provide a useful way of examining key social actors who shape the spread of neo-liberal higher education policies. For, as Scott (1998, p. 122) says, 'Not all universities are particularly international, but all are subject to the same processes of globalization - partly as objects, victims even, of these processes, but partly as subjects, or key agents, of globalization.' This is how we examine mechanisms and patterns of academic capitalism in Latin America.

Latin America is characterized by great variety in higher education systems and institutions. For all the variety, however, it is necessary to consider a commonality, which is the inequalities within the systems, and particularly between them and the higher education system of the USA. The US model, so evident in the policies of international organizations, has a powerful influence on Latin American institutions and systems of higher education, which in some regards and cases adapt key dimensions of this model and in others actively resist it. For our purposes, we consider the three 'megasystems' in the region Argentina, Brazil, and Mexico (Garcia Guadilla, 2000), which are significant because of their size. We also consider Chile because it was the first country in the region to establish neo-liberal reforms, and can be seen as the laboratory of the World Bank's efforts to shape Latin American systems.

Since World War II, international organizations have had a significant presence in the region. The most global of these have been the World Bank, the United Nations Educational, Scientific and Cultural Organization, and the Organisation for Economic Co-operation and Development. Significant regional organizations affecting higher education have included the InterAmerican Development Bank, the International Institute for Higher Education in Latin America and the Caribbean, the Economic Commission for Latin America and the Caribbean, the Organization of American States, and the Iberia-American States Organization for Education, Science, and Culture (Maldonado-Maldonado, 2003). These organizations have published documents which have had a major impact on the region (Comisión Económica para América Latina, 1990; Winkler, 1994; Task Force on Higher Education and Society, 2000; World Bank, 2002).

Although the reforms have taken different form from one country to the next, there are important common patterns. Throughout the region the 
reforms have promoted three interrelated neo-liberal policies: reduced public financing, evaluation and quality assurance, and increased tuition and privatization as a means for providing access. Each reflects the influence of the US model of academic capitalism.

During the 1980s Latin America had the lowest public financing of higher education of all regions in the world (Brunner et al, 1994), and this trend continued through the 1990s. The situation has been used by governments to impose stricter controls on resource allocation to universities, such as by linking financing to evaluation. National quality control bodies have been created throughout Latin America, reflecting the global pattern of an 'evaluative state' (Neave, 1998) that effects change through the mechanism of intermediate evaluative bodies. In many ways, the models of quality assurance and accreditation reflect some features of the US model (Rhoades \& Sporn, 2002), although taken to a more restrictive and national level than in American higher education. Thus, in Argentina, a national body was established in 1995, Comisión Nacional de Evaluación y Acreditación Universitaria. In Brazil, three bodies have been established: the National Council of Higher Education Evaluation (1993), the National Institute of Studies and Educational Research (1995), and the National Evaluation System (2002). In Chile, four councils were established: Consejo Superior de Educación (1990), Comisión Nacional de Acreditación Pregrado (undergraduate) (1998), Comisión Nacional de Acreditación Posgrado (1998), and the Sistema Nacional del Aseguramiento de la Calidad (quality assurance) de la Educación Superior (2002). In Mexico as well, four bodies have been created since 1989: Comisión Nacional de Evaluación (1989), Comités Interinstitucianales para la Evaluación de la Educación Superior (1991), Centro Nacional de Evaluación (1994), and the Instituto Nacional para la Evaluación de la Educación (2002).

For all the emphasis on quality, there is an interesting contradiction that emerges with respect to private higher education in Latin America. As governments have restricted the support and growth of public institutions, the demand for greater access has been accommodated by the expansion of private institutions of higher education and by new, non-university institutions. For example, in Mexico from the mid-1980s to 1999 only three public universities were created, as compared to 45 technological universities and 35 private universities. The private institutions generally charge relatively high tuition. And they are not subject to the same quality assurance mechanisms that public institutions are, leading to substantial questioning of their quality; the latter point is particularly true in Brazil. Moreover, governments are increasingly seeking to raise tuition in the public sector, shifting the costs to the consumer.

The privileging of private institutions in public policy and the promotion of higher tuition in the public sector reflect features of higher education policy in the USA (although there privates are privileged through financial aid policies, and non-university public institutions - community colleges - are the principal point of access for low income [and Latino] students). 
To what extent are these reforms shaped by international organizations? An analysis of their documents reveals a clear neo-liberal agenda (MaldonadoMaldonado, 2004). International organizations call for a restricting of public financing of higher education, for more diverse and more private higher education, for quality assurance mechanisms that link resource allocations to evaluation, and for shifting the costs of higher education from the state (as an investment in the public good) to the consumer (as an investment that is a private good, benefiting the individual). The mechanisms of influence are both coercive (e.g. the World Bank's structural adjustment policies - see Kempner \& Jurema, 2002) and normative. The latter sorts of processes involve the dissemination of publications that norm the Latin American national systems on an international standard (and in relation to each other), the creation of policy networks and the empowering through research and contract support of particular higher education policy groups that shape national policy. These are important mechanisms for influencing public policy in developing countries.

The connection to the academic capitalism model in the USA is relatively plain. For example, despite the World Bank's claim of neutrality, social scientists and practitioners have long recognized its direct link to the USA: 'In the first fifty years, the Bank did not begin to escape the charge that the United States had not only the heaviest weight but, compared with the legalities, a disproportionate one in the governance of the institutions' (Kapur et al, 1997, p. 3). Perhaps more importantly, the organizations promote a neo-liberal, market model that is premised on the success of the US higher education system and the ability to transfer it directly to other countries.

Yet what is transferred and applied often bears little resemblance to the US model in practice. Private institutions in the USA, for example, are subject to accreditation and quality assurance mechanisms. But these mechanisms are not directly linked, for the most part, to resource allocation. Access to higher education is primarily accomplished through low-tuition, public institutions of higher education. And the Federal Government provides enormous subsidies to facilitate the shifting of higher education costs to the consumer. None of these conditions applies in Latin American systems of higher education.

Finally, whatever the influence of the international organizations and the US model, the mechanisms through which that influence is translated into actual policies and practices in national and local settings depend on national and local 'experts'. Such individuals and groups, which can be conceptualized as 'epistemic communities', networks of professionals in policy domains (Haas, 1992), play an important role in shaping policy. It is important to consider their position in regard to academic capitalism, US style (Maldonado-Maldonado, 2004). For they are a key to understanding the distinctive adaptations of academic capitalism in Latin America. 


\section{Una Alternativa Distintiva de Universidad Privada Mexicana}

One of the leading private universities in Mexico provides an example of how the character of academic capitalism may be specified and vary significantly from one context to the next. It offers the possibility that entrepreneurial activity may go in some very different directions from what might be anticipated from the neo-liberal model of higher education being promoted by various international agencies.

The Instituto Tecnológico y de Estudios Superiores de Monterrey (ITESM), commonly known as Monterrey Tech, is the largest private university in Mexico. It is a university system that includes 33 campuses located in different cities and states. It offers undergraduate, Master's, and doctoral degrees. Its student body is about 100,000 . Founded in 1943 by a group of businessmen who were concerned about a perceived lack of highly skilled professionals in Mexico, Monterrey Tech was explicitly modeled on the Massachusetts Institute of Technology, which the Tech's creators had visited. This private university is one of only three Mexican universities accredited by the Southern Association of Colleges and Schools. It also has the recognition of the US Department of Education and is a member of the College Board. In these regards, one can already see some of the international influences discussed in the previous section of the article, although the particular mechanisms of influence are different.

Despite the number and strength of international influences, or more accurately in this case, of US influences, on Monterrey Tech, it nevertheless presents an example of a distinctive model of private higher education. ITESM is a private, non-profit university that operates in a country in which the public higher education sector is dominant and comprehensive, whereas the private sector is peripheral and more focused in orientation, though it is growing rapidly (Levy, 1986; Geiger, 1988). Monterrey Tech has focused its curriculum on professional degrees targeted to private-sector employment. However, in contrast to private universities in the USA such as MIT, it is focused on undergraduate education, and is characterized by relatively limited involvement in doctoral education and research, including applied research, particularly outside the Monterrey campus (it is interesting in this regard that it is not modeled more explicitly on selective liberal arts colleges in the USA). Still, it has adopted an orientation toward the private labor market that is far more explicit in various regards than is the case for public Mexican universities.

Another interesting contrast is found in the funding structure and configuration of revenue streams on which Monterrey Tech relies. Private higher education institutions in Mexico do not receive any direct financial support from public entities. That makes for a substantial contrast with elite private universities in the USA, which receive a large amount of public support directly, in the form of research grants, and a great deal of indirect support, through publicly underwritten financial aid. For Mexican private universities generally, and for ITESM, the principal revenue stream is from student tuition; but the only financial aid comes from the institutions themselves (in the case of 
Monterrey Tech, 33\% of its students receive such aid). There are preferential tax schemes in Mexico such that tuition for undergraduate programs is taxexempt, and tuition revenues are not taxed either. Private philanthropic donations are also tax-deductible, and Monterrey Tech collects capital through fund raising campaigns. But the campaigns pale in comparison to those of large public and private universities in the USA, with most of the monies coming from members of ITESM's Board. In fact, the second largest source of revenue for Monterrey Tech is not private gifts, but is the Sorteo Tec, which is a nationwide authorized lottery (for which companies donate prizes).

Two other distinctive features of Monterrey Tech, in comparison to its private-sector counterparts in the USA, lie in its commitment to and investment in global exchange and sustainable local community development. As with most selective private colleges and universities in the USA, Monterrey Tech has large study-abroad and exchange programs. Partly because of its interest in students developing proficiency in English to enable them to gain employment in the global economy, ITESM encourages its students to spend at least one academic term abroad. More than 7000 students participated in such a program in 2003. Moreover, ITESM has exchange programs with over 300 universities throughout the world, and has eight liaison offices in the USA, Canada, and Europe. Yet such activities are not undertaken to generate revenue. Thus, no service fees are charged to students who study abroad.

Similarly, social service has long been part of undergraduate education in Mexico, and Monterrey Tech has a targeted program for such service. Since 1945, by federal law undergraduate students in Mexico must complete at least 480 hours of social service, which can include activities related to students' professional major or community service. The activities can be carried out at the student's institution, or in the public or private sector. Higher education institutions are responsible for operating their own social service program, with the ideal being one in which the institution links its students with strategies to solve problems that affect the life of marginal communities (Mungaray \& Ocegueda, 1999; Bertín, 2000). Monterrey Tech's program requires a minimum of 240 hours of social community service, although most of the ITESM campuses require that more than 300 of the 480 total hours be devoted to such work. The emphasis on social service activity versus internship-like work in the profession is partly due to the fact that most students' practical work in the profession is already built into their formal coursework.

ITESM undergraduates are encouraged to participate in activities that promote the development of marginal communities and that focus on education, entrepreneurial skills, environment and ecology, health and hygiene, housing, and technical training (ITESM, 2001). Students take an Induction Workshop to acquire an understanding of community service. As Ernesto Benavides, Director of the Social Community Service program at ITESM, points out (personal interview), above all, Monterrey Tech operates these programs according to a model of self-management in fostering sustainable small business enterprises in poor communities. The idea is not to 
paternalistically provide temporary aid and relief, but rather to contribute to sustainable local community development, not unlike the micro-lending programs of some non-governmental organizations. Indeed, in 1997, ITESM began to focus its social community service program in each campus to a few communities in order to achieve a continuous, long-term development program of activities in them. There is also now an effort to link these programs more systematically with faculty members and academic programs.

The sorts of activities that fall within these community service programs are wide- ranging, and entailed in the last year over three million hours of student time. A few examples reflect the sort of work that is being done. One program involved the development of a denim clothing manufacturing business run by women in the community. Another involved the reconstruction of a medical clinic in the community. Yet another project entailed the construction of housing in poor communities, with the families themselves participating in the construction process and learning various skills, not unlike the model of Habitat for Humanity. In another case, students organized a literacy and math program for rural cheese producers to enhance their business skills. And still another project resulted in the creation of a 'Fundación la Paz Comienza con los Niños', that teaches courses in arts, sciences, and physical education to 750 children from foster homes. Each of these examples points to the targeting of poor local communities with the aim of establishing services and providing skills that will endure well beyond the life of the students' and institutions' activities. Of course, many people might question how successful and enduring these efforts are. As the organization of such targeted activities is relatively recent, it is probably too early to really tell in most cases. What is important for our purposes, though, is that this elite private university is providing an example of how a university can try to invest in, enhance, and work to effect sustainable change and improvement of the quality of life in local communities.

\section{Developing a Modelo Distintivo de Universidad Latinoamericana}

Historically, Latin American higher education acquired meaning and purpose within a long tradition established since the Universidad de Córdoba (Argentina) reform in 1918. The most salient features of this university tradition have been: university autonomy, shared governance, tuition-free higher education, and a strong commitment to the university's social and political responsibilities in national development, sovereignty and defending democracy. Notwithstanding at least three waves of university transformations - during the 1930s, 1940s, and late 1960s/early 1970s - Latin American universities were able to maintain their unique identity in the face of strong influences of university traditions from the United States. Indeed, nearly 40 years ago, Darcy Ribeiro (1969) pointed to attempts to establish an 'Americanization' project in Latin American higher education regarding the 
debates about humanism or practical orientations, elitism or massification, and science versus professionalism.

However, in the face of contemporary trends of higher education reforms, Latin American universities have lost much of their traditional identity. Universities have been forced by structural conditions - reduced public funding and privatization among others - to adopt policies and strategies that have been deemed successful by international experts and agencies in the establishment of entrepreneurial institutions. The identities, meaning, and purposes of higher education institutions in most Latin American countries are in the process of being lost in attempts to imitate policies and practices of internationally acclaimed research universities. Throughout Latin America, and particularly in Mexico, universities have been involved in marketization and privatization, diversifying their sources of funding and competing for financial resources (Mollis, 2003). Private investment in higher education has increased, and for-profit providers have emerged. Public institutions themselves are becoming service providers and are attempting to increase university-business connections. As outlined earlier, most countries have established complex evaluation systems, accountability measures, and accreditation and certification procedures for institutions, academic programs, and academics (Ordorika, 2004). These systems have been geared towards the competition for public funds and merit-pay income for faculty (Diaz Barriga \& Pacheco, 1997; Canales Sánchez, 2001; Ordorika, 2004). Despite limited private-sector markets for the production of knowledge and professionals, higher education systems and institutions in Latin America have adopted a market discourse and attempted to assimilate market practices into academic systems (Ordorika, 2002).

To some extent, changes in policies and practices in Latin America have been 'structurally adjusted' as part of World Bank and International Monetary Fund packages to address the fiscal and debt crises of countries (Carnoy $\&$ Samoff, 1990). At the same time, the changes have been quite politicized and in many cases strongly resisted. During the last 20 years, intense political confrontations have been a significant element of university life. In the face of tuition increases, privatization, and the loss of meaning and identity, universities have been the site and object of political conflicts, student movements, and faculty strikes. Most of these confrontations have been focused on resisting what have commonly been labeled as neo-liberal policies towards higher education.

Yet resistance has been based on the defense of a mystification or romanticization of Latin American universities. Much of the critical stances and understanding of the limitations of higher education institutions and policies in Latin America have been substituted by nostalgic attempts to 'restore' university traditions and practices that have become part of a myth. This romanticization of the history of Latin American universities provides little opportunity to go beyond resistance to create a new, indigenous identity for Latin American higher education. 
At the same time, attempts to mimic entrepreneurial Western (and particularly American) universities in the face of scarce resources, extremely constrained markets, economic subordination, and technological dependence are producing grotesque outcomes. 'Underdeveloped universities' try to resemble and compete with highly developed core universities in knowledge production, technology development and transfer, and cutting-edge research. In aspiring to emulate the core universities, universities in Latin America increasingly turn towards serving international and corporate markets and away from serving public-sector markets and the public good. There is a need to explore the particular nature and role of colleges and universities in peripheral, developing and underdeveloped regions in Latin America.

The creation of Latin American university identities, projects, and practices should be rooted in an historical understanding of and commitment to redressing the economic, political, and social realities of these countries. Latin American universities have long played a central national role in their societies. In a time of globalization, powerful international influences are pushing them to become academic capitalists, primarily intersecting with global markets at the expense of local and national needs, including economic ones. The challenge is for Latin American universities to use their historical role as a touchstone, on the basis of which they can identify critical issues that represent national projects to which higher education institutions can commit and in which they can invest. Alternatives to academic capitalism lie in alternatives to current patterns of neo-liberal development which involve sublimation to international business.

We identify three such alternatives as significant projects. One is focused on democratization, not only of access to higher education but of governance and politics in society. How to link higher education more to the promotion of increased access as a public good, and to support it more as a public investment? And how to feature more prominently and support more systematically the democratic role of universities in Latin America, not only as social critics or as political insiders, but as institutions that contribute to strengthen the institutional foundations in local, state, and national communities of democratic processes, debates, and practices? A second project is independent development, not only economically but socially. In what ways can Latin American universities contribute to the sustainable economic vitality of local and regional communities, and of the nation as a whole? And how can these universities play a role in expanding infrastructures that support public health, literacy, and education? Finally, a third project is that of sovereignty and cultural distinctiveness. In pursuing their own distinctive identities, Latin American universities should consider how they might contribute to building new and sovereign cultural identities in their countries, in ways that draw on the past but also look to the future. And they should commit to the development and fostering of new economy commerce that expresses, advances, and contributes to strengthening that identity, whether in the media and fine arts or in the humanities. Several years ago, one of the co-authors 
heard an English professor at a conference in the United Kingdom (UK) argue that what was most marketable in Britain in the global economy was not technology, but high culture. Global markets are more likely to find Jane Austen, Shakespeare, the BBC, and other forms of English culture more attractive than British technology. Without arguing that either the British or Latin American universities ought not to play the science and engineering game, at least in global markets, there is much room for a greater emphasis currently on the sovereign identities and cultural contributions of Latin America. For example, as with the UK, what indigenous high technology has been as successful globally as the literary contribution of magical realism?

In closing, then, we suggest that Latin American universities play to their strengths and to their historical national roles in developing a modelo distintivo

de universidad latinoamericana. In our minds, the most feasible and successful future for these institutions lies not in a path of emulating academic capitalism, US style; rather, it lies in drawing on their own distinctive strengths in addressing the challenging national projects of the future.

\section{References}

Bertin, G.I. (2000) El servicio social en México. Available at: www.anuies.mx/principal/ servicios/publicaciones/libros/lib50/43.htm

Bok, D. (2003) Universities and the Marketplace: the commercialization of higher education. Princeton: Princeton University Press.

Brunner, J.J., Balán, J., Courard, C. \& Cox, C. (1994) Educación superior en América Latina: una agenda de problemas, politicas y debates en el umbral del año 2000. Santiago: Facultad Latinoamericana de Ciencias Sociales.

Canales Sánchez, A. (2001) La experiencia institucional con los programas de estímulo: la UNAM en el periodo 1990-1996. Mexico: DIE, CIN VESTAV.

Carnoy, M. \& Samoff, J. (1990) Education and Social Transition in the Third World. Princeton: Princeton University Press.

Chua, A. (2003) World on Fire: how exporting free market democracy breeds ethnic hatred and global instability. New York: Doubleday.

Clark, B.R. (1998) Creating Entrepreneurial Universities: organizational pathways of transformation. Oxford: IAU Press and Pergamon.

Comisión Económica para América Latina (CEPAL) (1990) Transformación productiva con equidad. Santiago: CEPAL.

Currie, J. \& Newson, J.A. (Eds) (1998) Universities and Globalization: critical perspectives. Thousand Oaks: Sage.

Diaz Barriga, A. \& Pacheco, T. (1997) Universitarios, institucionalización académica y evaluación, in Pensamiento Universitario, 86, p. 210. Coyoacan: Universidad Nacional Autónoma de México, Coordinación de Humanidades, Centro de Estudios sobre la Universidad.

Garcia Guadilla, C. (2000) Latin America: higher education research in a transformation context, in U. Teichler \& J. Sadlak (Eds) Higher Education Research: its relationship to 
policy and practice. Oxford: IAU Press, Pergamon, United Nations Educational, Scientific and Cultural Organization (UNESCO).

Geiger, R.L. (1988) Public and Private Sectors in Higher Education: a comparison of international patterns, Higher Education, 17, pp. 699-711.

Haas, P.M. (1992) Introduction: epistemic communities and international policy coordination, International Organization, 46, pp. 1-35.

Instituto Tecnológico y de Estudios Superiores de Monterrey (ITESM) (2001) Reglamento general del servicio social comunitario y profesional para los alumnos de Sistema Tecnológico de Monterrey. Monterrey: ITESM.

Kapur, D., Lewis, P. \& Webb, R. (Eds) (1997) The World Bank: its first half century. Washington, DC: Brookings Institution Press.

Kempner, K. \& Jurema, A.L. (2002) The Global Politics of Education: Brazil and the World Bank, Higher Education, 43, pp. 331-354.

Levy, D.C. (1986) Higher Education and the State in Latin America: private challenges to public dominance. Chicago: University of Chicago Press.

Maldonado-Maldonado, A. (2003) Investigación sobre organismos internacionales a partir de 1990 en México, in P. Ducoing (Ed.) La investigación educativa en México. 'Sujetos, actores y procesos de formación', formación para la investigación. Los académicos en México, actores y organizaciones. Mexico: COMIE-SEP-CESU.

Maldonado-Maldonado, A. (2004) The Influence of International Organizations in the Field of Higher Education in Latin America: the analysis of one epistemic community in Mexico. Doctoral dissertation, Boston College.

Marginson, S. \& Considine, M. (2000) The Enterprise University: power, governance, and reinvention in Australia. Cambridge: Cambridge University Press.

Marginson, S. \& Rhoades, G. (2002) Beyond National States, Markets, and Systems of Higher Education: a glonacal agency heuristic, Higher Education, 43, pp. 281-309.

Mollis, M. (Ed.) (2003) Las universidades en América Latina: reformadas o alteradas. Buenos Aires: Consejo Latinoamericano de Ciencias Sociales.

Mungaray, A. \& Ocegueda, J.M. (1999) El servicio social y la educación superior frente a la pobreza extrema en México. Asociación Nacional de Universidades e Instituciones de Educación Superior. Mexico City: ANUIES.

Neave, G. (1998) The Evaluative State Reconsidered, European Journal of Education, 33, pp. 265-284.

Ordorika, I. (2002) Mercados y educación superior, Perfiles Educativos, XXIV(95), pp. $98-103$

Ordorika, I. (2004) El mercado en la academia, in La academia en jaque: perspectiva politica sobre la evaluación en México. Mexico: CRIM-UNAM/Miguel Angel Porrua.

Rhoades, G. \& Sporn, B. (2002) Quality Assurance in Europe and the US: professional and political economic framing of higher education policy, Higher Education, 43, pp. 355-390.

Ribeiro, D. (1969) A universidade necessária. Rio de Janeiro: Paz e Terra.

Scott, P. (1998) The Globalization of Higher Education. Buckingham: Open University Press.

Slaughter, S. \& Leslie, L.L. (1997) Academic Capitalism: politics, policies, and the entrepreneurial university. Baltimore: Johns Hopkins University Press. 
Slaughter, S. \& Rhoades, G. (2004) Academic Capitalism and the New Economy. Baltimore: Johns Hopkins University Press.

Task Force on Higher Education and Society (2000) Higher Education in Developing Countries: peril and promise. Washington, DC: World Bank-UNESCO.

Waters, M. (1995) Globalization. London: Routledge.

Winkler, R.D. (1994) La educación superior en América Latina. Cuestiones sobre eficiencia y equidad. Washington, DC: Banco Mundial.

World Bank (2002) Constructing Knowledge Societies: new challenges for tertiary education. Washington, DC: World Bank.

GARY RHOADES is Professor and Director of the University of Arizona's Center for the Study of Higher Education. His research focuses on the restructuring of academic organizations and professions. His latest books are Managed Professionals (SUNY Press, 1998) and (with Sheila Slaughter) Academic Capitalism and the New Economy (Johns Hopkins University Press, 2004). Correspondence: Dr Gary Rhoades, College of Education, Room 319, University of Arizona, PO Box 210069, Tucson, AZ 85721-0069, USA (grhoades@, email.arizona.edu).

ALMA MALDONADO-MALDONADO is Assistant Professor of Higher Education at the University of Arizona's Center for the Study of Higher Education. Her research concentrates on international organizations and their influence on higher education policy and centers in developing countries. Correspondence: Alma Maldonado-Maldonado, University of Arizona, PO Box 210069, Tucson, AZ 85721-0069, USA (maldona2@email.arizona.edu).

IMANOL ORDORIKA is Professor of Political Economy at the Universidad Nacional Autonoma de Mexico. His research concentrates on the intersection of politics and higher education governance and organization in Mexico.

Correspondence: Dr Imanol Ordorika, Curry School of Education, University of Virginia, 182 Ruffner Hall, Charlottesville, VA 22904, USA (ordorika@servidor.unam.mx).

MARTÍN VELAZQUEZ is a doctoral student at the University of Arizona's Center for the Study of Higher Education, and a former campus president of the ITESM campus at Leon. Correspondence: Martin Velazquez, University of Arizona, PO Box 210069, Tucson, AZ 85721-0069, USA. 